NOTE

\title{
Chytridiomycosis in dwarf African frogs Hymenochirus curtipes
}

\author{
B. G. Murphy ${ }^{1, *}$, C. Hillman ${ }^{1}$, J. M. Groff ${ }^{2}$ \\ ${ }^{1}$ Department of Pathology, Microbiology and Immunology and ${ }^{2}$ Pathology Service, \\ The William R. Pritchard Veterinary Medical Teaching Hospital, School of Veterinary Medicine, University of California, \\ Davis, CA 95616-5270, USA
}

\begin{abstract}
Chytridiomycosis, resulting from an infection with the fungal agent Batrachochytrium dendrobatidis $(B d)$, has resulted in widespread population declines in both wild and captive amphibians. The dwarf African frog (DAF) Hymenochirus curtipes is native to central Africa and is commonly sold throughout North America as an aquarium pet species. Here we document fatal chytridiomycosis resulting from cutaneous $B d$ infections in DAF purchased directly from a pet store and from a historical lethal epizootic occurring at an aquaculture facility in central California, USA, more than $25 \mathrm{yr}$ ago. Histological lesions and PCR-amplified sequence data were consistent with the etiology of $B d$. The potential epidemiological relevance of this infection in DAF is discussed.
\end{abstract}

KEY WORDS: Frog $\cdot$ Batrachochytrium dendrobatidis $\cdot B d \cdot$ Hymenochirus $\cdot$ Chytridiomycosis

Resale or republication not permitted without written consent of the publisher

\section{INTRODUCTION}

Chytridiomycosis, resulting from an infection with the chytridiomycete fungus Batrachochytrium dendrobatidis $(B d)$, has caused dramatic declines in amphibian populations around the world. Chytridiomycota are heterotrophic fungi that are ubiquitous and cosmopolitan (Sparrow 1960, Karling 1977). Chytridiomycota have been demonstrated to maintain infectivity for up to $7 \mathrm{wk}$ in lake water (Johnson et al. 2003). $B d$ is found in both soil and water, acting as a primary saprobe using substrates such as chitin, keratin and plant detritus (Berger et al. 1998). At least 3 amphibian orders, Anura, Caudata and Gymnophiona, have been diagnosed with chytridiomycosis (Boyle et al. 2004, Churgin et al. 2013). Bd has been identified in zoo collections (Pessier et al. 1999), the pet trade (Mutschmann et al. 2000), the food trade (Mazzoni 2003) and the laboratory animal trade
(Parker et al. 2002). The pathogenesis, diagnosis and treatment of $B d$-infected amphibians have recently been reviewed (Baitchman \& Pessier 2013).

The relatively sudden appearance of chytridiomycosis can be explained by the hypothesis that $B d$ was recently introduced into new regions of the world, facilitating the infection of new amphibian species (Daszak et al. 1999). Bd is a common infectious agent in African frogs from Ghana, Kenya and South Africa (Weldon et al. 2004). African frogs that have been widely exported from Africa include members of the Pipidae family, specifically, the African clawed frog (ACF) Xenopus spp. and the dwarf African frog (DAF) Hymenochirus spp. (Hey 1986). Xenopus spp. were widely exported starting in the 1930s for use in pregnancy diagnosis, as laboratory animal models and as aquarium pets, while Hymenochirus spp. were disseminated widely in the aquarium pet trade. It has been proposed that international trade of ACF 
during the 20th century resulted in worldwide dissemination of the chytridiomycete fungal agent (Weldon et al. 2004). Multiple states in the USA now require a permit to purchase $\mathrm{ACF}$.

$\mathrm{ACF}(X$. laevis) in the wild do not demonstrate clinical signs of chytridiomycosis, and sudden die-offs of ACF have not been documented (Weldon et al. 2004). However, subclinical infections with $B d$ have been well documented in captive Xenopus laevis (Reed et al. 2000). In contrast, $B d$ infection in the related ACF $X$. tropicalis can result in anorexia and lethargy, cutaneous pigment changes, loss of the cutaneous slime layer and death (Parker et al. 2002). In a survey of archived specimens of 3 different species of Xenopus from 1879 to 1999, the earliest case of chytridiomycosis was found in a Xenopus laevis frog in 1938 (Weldon et al. 2004). This fungal pathogen apparently existed as a stable endemic infection in southern Africa for at least $23 \mathrm{yr}$ before any $B d$-infected specimens appeared outside of Africa (Weldon et al. 2004).

Dwarf African frogs are small aquatic frogs native to central Africa that lack both teeth and a tongue and are completely aquatic. Otto Boettger, one of the dwarf African frog discoverers, originally named them African dwarf clawed frogs in recognition of the small black claws on their hind legs. Since these claws are often lost as the frogs mature, these animals are now more commonly referred to as dwarf African frogs. There are currently 4 recognized species of Hymenochirus: $H$. boulengeri, $H$. curtipes, $H$. boettgeri, and $H$. feae (IUCN Red List of Threatened Species, www.iucnredlist.org). Currently, there is some controversy over the taxonomic status of $H$. feae. Both $H$. boettgeri and $H$. curtipes are commonly sold in the pet trade. As these animals look very similar to one another, the morphological separation between these 2 species can be challenging. In addition, these frogs are capable of interbreeding and forming hybrids; as a result, some breeders feel that the DAF sold in the pet trade are actually a $H$. boettgeri $\times H$. curtipes hybrid.

The peer-reviewed literature has a single previous report of chytridiomycosis in DAF $(H$. boettgeri) (Raverty \& Reynolds 2001). Here we document fatal chytridiomycosis lesions and PCR-amplified and cloned $B d$ sequences isolated from $2 \mathrm{H}$. curtipes individuals directly purchased from a pet store. In addition, our group re-evaluated the etiology of a published fatal cutaneous mycotic epizootic in $H$. curtipes from a central California aquaculture facility that occurred from 1985 to 1987 (Groff et al.
1991). In this report, the causative mycotic agent was originally identified as Basidiobolus ranarum. Here, based upon lesion morphology (cutaneous hyperkeratosis), characteristic fungal thalli and new sequencing data, we more accurately define the causative outbreak etiology as $B d$.

\section{MATERIALS AND METHODS}

\section{Animals}

Two DAF (Hymenochirus curtipes, frogs A and B, Table 1) were purchased from a local pet store in 2010 and maintained in a small, established 71 aquarium with locally obtained aquatic plants (hornwort Ceratophyllum demursum), aquatic snails, deionized water and gravel substrate. The frogs were found dead approximately $1 \mathrm{wk}$ after purchase and were immediately immersed in $10 \%$ buffered formalin. Other than anorexia, clinical signs of morbidity were not evident perimortem.

From 1985 to 1987, 5 submissions for a total of approximately 75 post-metamorphic DAF (H. curtipes), approximately $0.25 \mathrm{~g}$ in weight, were submitted to the Fish Pathology Laboratory at the School of Veterinary Medicine, University of California, Davis, from a private culture facility in central California (Groff et al. 1991). The culturist reported a sustained increased mortality of post-metamorphic frogs that often approached $100 \%$, with a cumulative total of approxi-

Table 1. Details and sources of individual specimens of dwarf African frogs Hymenochirus curtipes described in this study. For the histologic lesions, ' +++ ' indicates severe while ' + ' indicates mild severity. For PCR, ' + ' indicates a successful amplification while ' - ' indicates an unsuccessful amplification. Clones refers to PCR amplicons that were subsequently cloned into plasmids, amplified in bacteria and sequenced

\begin{tabular}{|llccc|}
\hline $\begin{array}{l}\text { Frog } \\
\text { ID }\end{array}$ & Source (year acquired) & $\begin{array}{c}\text { Histologic } \\
\text { lesions }\end{array}$ & PCR & Clones \\
\hline A & Pet store (2010) & +++ & + & 2 \\
B & Pet store (2010) & +++ & + & 2 \\
C & Direct from culturist (1985) & + & - & \\
D & Direct from culturist (1986) & + & - & \\
E & Experimental infection (1987) & + & + & 2 \\
F & Experimental infection (1987) & + & + & 2 \\
G & Experimental infection (1987) & + & + & \\
H & Experimental infection (1987) & + & + & \\
I & Experimental infection (1987) & + & + & \\
J & Experimental infection (1987) & + & - & \\
K & Experimental infection (1987) & + & - & \\
L & Experimental infection (1987) & + & - & \\
M & Experimental infection (1987) & + & - & \\
\hline
\end{tabular}


mately 10000 frogs. Affected sentinel frogs (1985 and 1986) exhibited a preference for the terrestrial environment rather than their normal aquatic environment a few days prior to death. External examination of dead sentinel frogs (Frogs $C$ and D, Table 1) was unremarkable except for a slight pallor of the integument.

In 1987, an attempt was made to experimentally transmit the etiologic agent to naive DAF. Two moribund-infected sentinel frogs (different animals from Frogs $C$ and D) and 12 healthy uninfected control frogs were co-incubated together in a 201 aquarium for $10 \mathrm{~d}$ at $20^{\circ} \mathrm{C}$. The aquaria received well water at a flow rate of $0.1 \mathrm{l} \mathrm{min}^{-1}$. A control group of 12 healthy frogs was maintained in similar conditions without exposure to moribund frogs. After $10 \mathrm{~d}, 9$ DAF became moribund during this experimental transmission (Frogs E-M, Table 1). Moribund animals were humanely euthanized with an overdose of $500 \mathrm{mg}$ tricaine methanesulfonate (MS-222) per $\mathrm{ml}$ of water. Postmortem, a midline incision was made in the coelomic cavity and the frogs were immediately fixed in Davidson's solution for $24 \mathrm{~h}$ and then transferred to $70 \%$ ethanol.

Post-fixation, 13 individual frogs (A-M) were mounted either whole or in transverse serial sections in separate tissue cassettes, paraffin embedded and routinely processed into $5 \mu \mathrm{m}$ thick, hematoxylin and eosin-stained slides. Two veterinary pathologists (B. G. Murphy and J. M. Groff) examined the histological sections.

\section{DNA extraction}

For all 13 DAF (A-M), 3 scrolls ( $25 \mu \mathrm{M}$ each) were cut with a microtome from each tissue-embedded paraffin block for DNA isolation. During this process, the knife blade and gloves were replaced between blocks to avoid cross-contamination of samples. The paraffin was dissolved by adding $1 \mathrm{ml}$ of xylene to the scrolls, incubating the samples for $10 \mathrm{~min}$ at room temperature, followed by centrifugation at $17000 \times g$ for an additional $10 \mathrm{~min}$. The supernatant was removed to a waste container and the incubation and centrifugation procedure was repeated twice more. The tissue was subsequently washed with a graded ethanol series $(100,90$ and $70 \%)$ followed by centrifugation at $17000 \times g$ for $10 \mathrm{~min}$ after each wash. After the last wash, the tissue was air-dried at room temperature for $7 \mathrm{~min}$. A column-based DNA isolation kit was used to lyse the tissue, precipitate and bind the DNA to the column, and finally wash and elute the DNA (QIAamp DNA FFPE tissue kit, Qiagen).

\section{PCR}

Standard PCR was performed with DNA isolated from all 13 DAF (A-M). Standard PCR was performed with Taq DNA polymerase (Invitrogen) on an Eppendorf Mastercycler. Primers utilized for amplifying the 5.8s rRNA gene from $B d$ were as follows: $\mathrm{BAT}_{\text {for }} 5^{\prime}$-CCT TGA TAT AAT ACA GTG TGC and BAT $_{\text {rev }}$ 5'-AGC CAA GAG ATC CGT TGT CAA (Boyle et al. 2004). The primers were used in the following cycling conditions: $95^{\circ} \mathrm{C}$ for 2 min followed by 40 cycles of $95^{\circ} \mathrm{C}$ for $15 \mathrm{~s}, 56^{\circ} \mathrm{C}$ for $30 \mathrm{~s}, 72^{\circ} \mathrm{C}$ for $30 \mathrm{~s}$, followed by a final elongation step at $72^{\circ} \mathrm{C}$ for $5 \mathrm{~min}$. PCR amplicons were analyzed on $2 \%$ agarose/ethidium bromide gels; the predicted amplicon size was $146 \mathrm{bp}$. After the initial successful PCR with DNA extracted from Frogs A and B, DNA from one of these animals served as a positive control in subsequent PCR. A negative control sample (water template) was run in parallel each time that the PCR was performed. Appropriate-sized PCR amplicons were cloned and sequenced.

\section{Cloning and sequencing}

PCR amplicons of the correct size were TA cloned into pCR2.1 (TA Cloning Kit, Invitrogen) following the manufacturer's protocol and incubated overnight at $14^{\circ} \mathrm{C}$. The following day, the ligation reaction was transformed into chemically competent TOP 10 E. coli bacteria (Invitrogen) and grown overnight at $37^{\circ} \mathrm{C}$ on Luria-Bertani broth agar plates containing $100 \mu \mathrm{g} \mathrm{ml}^{-1}$ carbenicillin, $40 \mu \mathrm{g}$ $\mathrm{ml}^{-1} \mathrm{X}$-gal, and $100 \mu \mathrm{M}$ isopropyl- $\beta$-D-thiogalactopyranoside (standard blue/white cloning). Individual white bacterial colonies (5 clones sample $^{-1}$ ) were inoculated into $5 \mathrm{ml}$ of LB broth containing $100 \mu \mathrm{g} \mathrm{ml}{ }^{-1}$ carbenicillin, placed at $37^{\circ} \mathrm{C}$, and shaken overnight at $225 \mathrm{rpm}$. Plasmid DNA was purified (Wizard Plus SV Miniprep DNA Purification System, Promega), digested with EcoRI (New England BioLabs), and visualized using agarose gel electrophoresis. Plasmid clones containing the correct-sized insert were sent to a local vendor $(2-3$ clones sample ${ }^{-1}$ ) for sequencing (Davis Sequencing). Putative $B d$ sequences were digitally compared to the GenBank database using the Basic Local Alignment Search Tool (BLAST, NCBI; www.ncbi.nlm.nih.gov/blast/Blast.cgi). Representative sequences were digitally aligned and compared (Vector NTI, Invitrogen). 


\section{RESULTS}

\section{Pathology}

No gross changes were evident in the animals purchased from the pet store (Frogs A and B), and histological lesions were confined to the skin. Histologically, the epidermis was multifocally acanthotic with orthokeratotic to parakeratotic hyperkeratosis. $\mathrm{Nu}$ merous round to oval, 7-15 $\mu \mathrm{m}$ diameter non-hyphal fungal thalli (sporangia) multifocally disrupted the cutaneous stratum spinosum and stratum corneum, most frequently at the junction of these 2 layers (Fig. 1). Fungal thalli were either empty or contained 4 to more than 10 basophilic zoospores $(1-2 \mu \mathrm{m}$ in diameter). Several empty thalli contained fine, eosinophilic septations (colonial thalli). In areas of heavy fungal infiltration, keratinocytes often exhibited ballooning degeneration. Ulceration and inflammation were not features of this lesion. The cutaneous lesions in Frogs A and B were most severe on the junction of the body and pelvic or pectoral limbs and distal limbs/feet (Fig. 1). Cutaneous tubercles

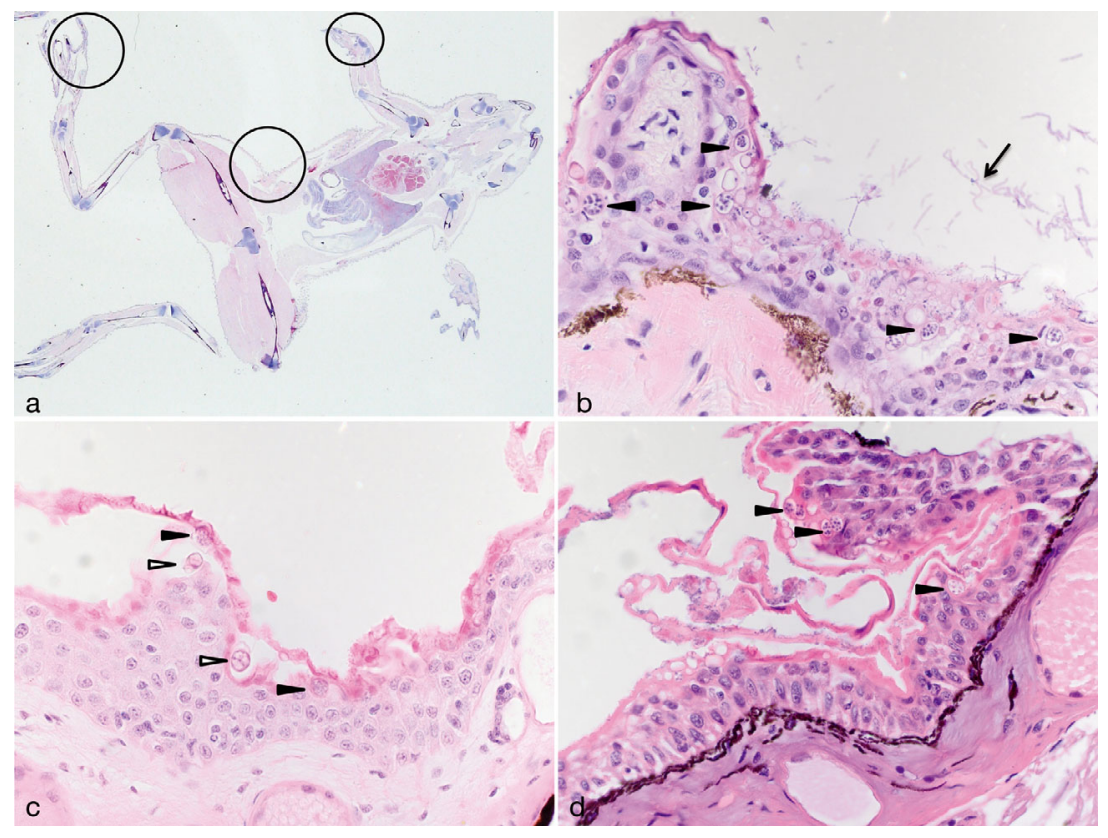

Fig. 1. Histopathology of dwarf African frogs Hymenochirus curtipes. (a) Regions of high fungal burden in Frog A (circles, digital photograph of mounted specimen, H\&E stain). (b-d) 600× magnification of histological sections of skin (H\&E). (b) Frog B, showing numerous fungal thalli filled with multiple basophilic zoospores sprinkled within the hyperplastic and hyperkeratotic epithelium (arrowheads). Abundant bacterial rods often forming chains are loosely attached to the skin (arrow). (c) Frog C, with several zoospore-containing thalli (black arrowheads) along with 2 empty thalli (white arrowheads). (d) Frog E, showing multiple zoospore-containing thalli (arrowheads) within the hyperplastic and hyperkeratotic epithelium ('warts') on the body wall and proximal hind legs were often severely affected.

In both Frogs A and B, large numbers of variably sized bacterial rods, both individualized and in chains, were multifocally to diffusely associated with the surface of the hyperkeratotic stratum corneum. Rarely, $20 \mu \mathrm{m}$ diameter ciliates were identified attached to the skin surface (not shown). Although bacterial rods were also abundantly attached to the skin of Frogs A and B, bacteria and oomycetes (Saprolegnia spp.) are known to commonly overgrow on carcasses of deceased amphibians. Tissues examined histologically and considered to be normal included skeletal muscle, bone, brain, spinal cord, eyes, nasal pit, oral cavity, intestine, liver and heart. The esophagus, stomach, lung and kidney were not visualized in the sections examined.

In the historical 1987 experimental transmission study, co-habitation of 12 normal frogs with 2 moribund frogs obtained directly from the culturist resulted in 9 animals becoming moribund (Frogs E-M). Two additional animals obtained directly from the culturist (sentinel Frogs C and D in 1985 and 1986, respectively) were submitted dead. In all of these archived frog tissues, lesions were similar to those identified in Frogs A and B, were confined to the skin, and were considered to be less severe (both reduced severity of hyperkeratosis and reduced number of fungal organisms) than those in Frogs A and B (Fig. 1). As sentinel animals C and D naturally succumbed to the fungal infection, it would appear that even modest cutaneous lesions with small numbers of fungal organisms are sufficient to result in death in DAF. There was no evidence of infection or morbidity in the unexposed control frogs.

\section{PCR and sequence alignments}

Agarose gel electrophoresis of PCR amplicons from Frogs A and B were appropriately sized (approximately $150 \mathrm{bp}$, lanes 1 and 2, Fig. 2). PCR amplicons derived from frogs E-I (1987 historical experimental transmission) were also approximately $150 \mathrm{bp}$ long (data not shown). Attempts to PCR amplify $B d$ sequences from sentinel Frogs $C$ and $D$ (1985 and 1986) and experimentally in- 
fected frogs J-M (1987) were not successful. PCR products amplified from samples derived from Frogs A, B, E and F were subsequently cloned and sequenced.

Cloned putative $B d$ amplicons derived from Frogs A, B, E and F (2 clones from each frog, 8 total se-

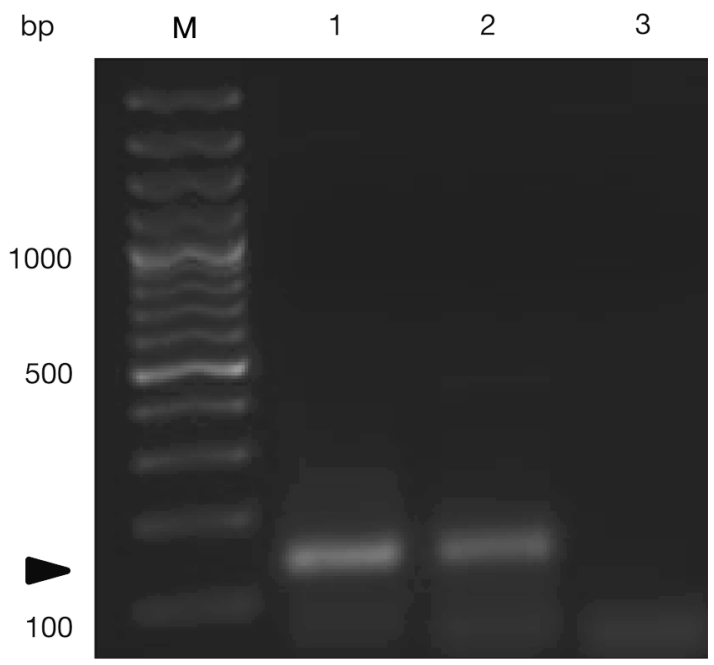

Fig. 2. Agarose gel electrophoresis of $150 \mathrm{bp}$ PCR amplicons derived from dwarf African frog Hymenochirus curtipes individuals A and B (lanes 1 and 2, respectively). Lane 3: negative control (water template). The amplicon in lane 3 $(<100 \mathrm{bp})$ is a primer concatemer. M: molecular ladder; arrowhead is located at approximately $150 \mathrm{bp}$ quences) were aligned and compared (Fig. 3). All of the sequences aligned most closely with $B d$ in a BLAST search. The sequences of clones A1, B2 and F2 were identical and were $100 \%$ consistent with GenBank Bd clone CW34 (JQ582938). All of the other clones (A2, B1, E1, E2 and F1) were unique, but were closely related. The overall sequence conservation in the amplified region was $98.6 \%$. Sequence changes included single nucleotide polymorphisms (SNPs), single base insertions or a short polymorphic region. A 7 bp region of variability was identified between nucleotides 79 to 85 (Fig. 3).

\section{DISCUSSION}

Here we demonstrate appropriate histological lesions and PCR-amplified DNA sequences consistent with the diagnosis of fatal chytridiomycosis in 2 pet store-purchased Hymenochirus curtipes individuals and in archived DAF tissues derived from an experimental infection in $11 \mathrm{H}$. curtipes DAF from 1987. Although appropriate cutaneous lesions and fungal organisms were identified in the archived sentinel DAF obtained directly from the culturist (Frogs $\mathrm{C}$ and D, 1985 and 1986), we were unable to PCR-amplify $B d$ sequences from these archived tissues. This is likely the result of both the relative scarcity of the cu-

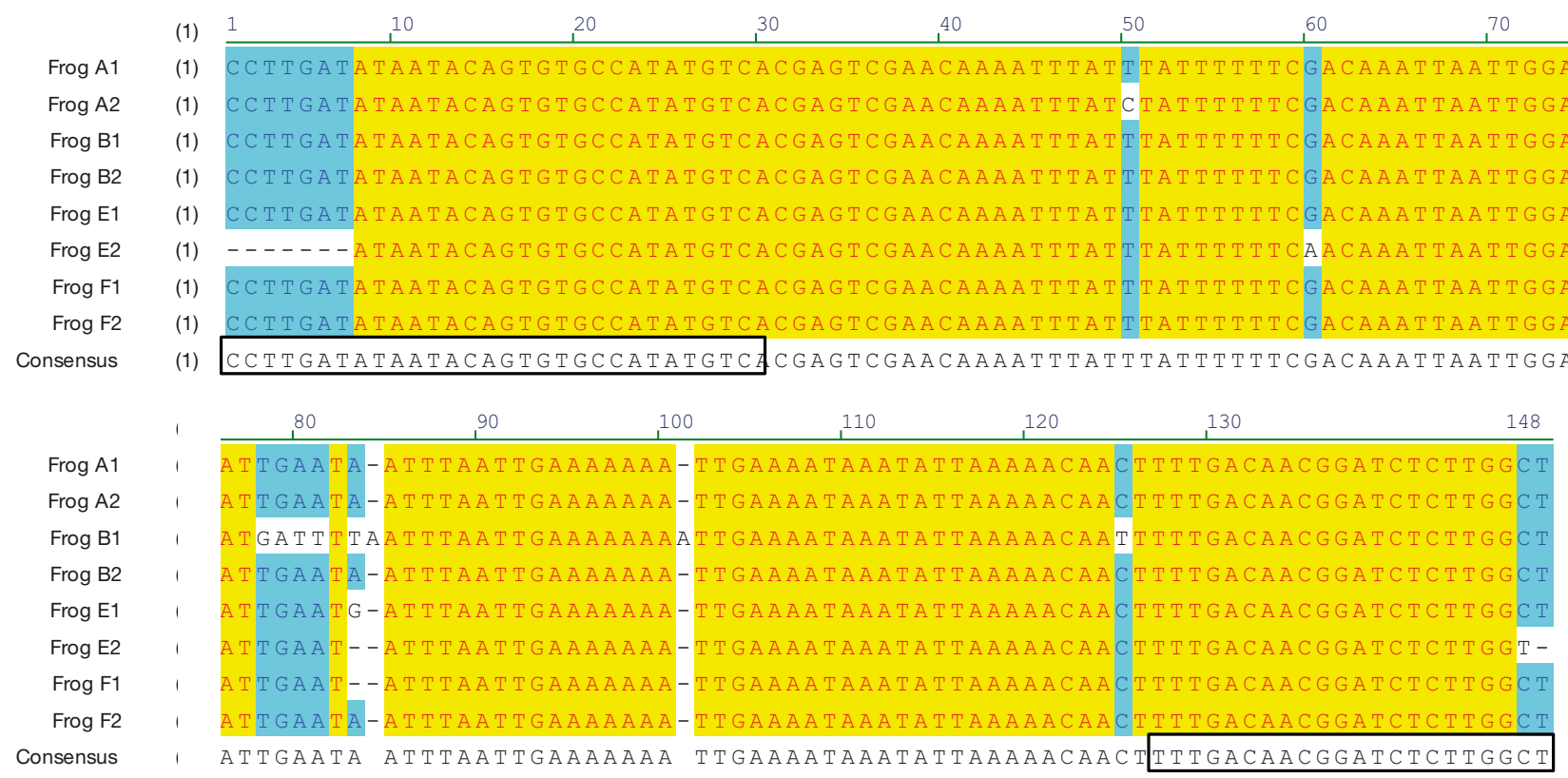

Fig. 3. Batrachochytrium dendrobatidis sequence alignment for the junction of the rDNA internal transcribed spacer (ITS-1) and 5.8S region derived from dwarf African frog Hymenochirus curtipes individuals A, B, E, and F (2 clones from each sample). The forward and reverse primers are designated by black boxes. Yellow regions are conserved, blue nucleotides are polymorphic, and dashes indicate one of the sequences has an insertion at this locus 
taneous lesions and low numbers of organisms along with degradation of DNA in the archived paraffin blocks over time, a period of almost $30 \mathrm{yr}$.

The first documented cases of chytridiomycosis in North America were in the bronze frog Rana (Lithobates) clamitans in 1961 (Weldon et al. 2004) and the northern leopard frog $R$. (L.) pipiens collected in 1974 (Carey et al. 1999). Although these dates obviously precede the occurrence of chytridiomycosis in dwarf African frogs documented here by several decades, it is possible that widespread distribution of DAF through the pet trade may have contributed to the worldwide amphibian chytridiomycosis epizootic. Therefore, in regard to the global dissemination of chytridiomycosis, establishing the first occurrence of this lesion in North American DAF may be epidemiologically relevant.

Although relatively little has been published in the peer-reviewed literature concerning chytridiomycosis infections in Hymenochirus species (Raverty \& Reynolds 2001), such infections appear to be common knowledge among aquatic frog hobby groups. Retail stores selling aquatic pets have been known to intermingle young Xenopus spp. with young Hymenochirus spp. (DAF) (authors' pers. obs.). This practice could potentially facilitate the transmission of the fungus from carrier ACF to DAF. During the past decade, internet-based aquarium hobby groups have reported many North American cases of pet storepurchased DAF dying within 2 mo of purchase; many of these deaths are suspected to be the result of chytridiomycosis (www.theaquariumwiki.com).

Cutaneous chytrid infections are confined to stratified squamous keratinized skin. For this reason, premetamorphic frogs (tadpoles) are only infected in anatomical regions that are keratinized (i.e. mouth parts; Berger et al. 1998). As such, widespread chytrid-associated mortality is generally not reported in tadpoles. As the skin of larval amphibians begins to keratinize during metamorphosis, mortality increases as the fungus moves from the mouthparts to colonize the skin (Rachowicz \& Vredenburg 2004). The non-keratinized epithelia in post-metamorphic anurans (conjunctiva, nasal cavity, mouth, intestines) are not infected, emphasizing the strictly keratinophilic affinity of this pathogen (Berger et al. 1998).

Although inflammation and ulceration are generally not histologically evident in this fatal cutaneous infection, cutaneous fungal colonization leads to pronounced physiologic derangement. Cutaneous hyperplasia and hyperkeratosis lead to massive depletion of electrolytes. In experimental studies, all electrolyte transport across infected amphibian skin was de- creased, with resulting decreases of all plasma electrolytes, especially sodium and potassium (Voyles et al. 2009, Marcum et al. 2010).

Although the cutaneous lesions in the DAF described here were consistent with chytridiomycosis, PCR amplification and sequencing were pursued in order to further validate this etiologic diagnosis. In addition, we aimed to more accurately define the etiology of a 1991 peer-reviewed study historically establishing the etiology of a cutaneous fungal epizootic infection in DAF as Basidiobolus ranarum (Groff et al. 1991). In this earlier study, a broth culture of $B$. ranarum was utilized to inoculate DAF. Importantly, there was no clinical or microbiological evidence of infection in the frogs exposed to the broth cultures of B. ranarum (Groff et al. 1991).

It has been well documented that carrier Xenopus spp. ACF were widely distributed throughout the world during the twentieth century. Young ACF were often mixed with DAF in aquatic pet stores, potentially facilitating the transfer of subclinical $B d$ to the susceptible Hymenochirus spp. During the past 2 decades, DAF have dramatically increased in popularity as an interesting and easy to maintain pet aquarium species. We suggest that this infection/susceptibility/distribution scenario may have magnified and facilitated the global chytridiomycosis pandemic in aquatic amphibians.

Acknowledgements. We are indebted to Dr. Allan Pessier for originally suggesting to J.M.G. that the published etiology in the 1991 report (Groff et al. 1991) might be in error. We also thank Dr. Ronald P. Hedrick for his advice and interest in this study.

\section{LITERATURE CITED}

Baitchman EJ, Pessier AP (2013) Pathogenesis, diagnosis, and treatment of amphibian chytridiomycosis. Vet Clin North Am Exot Anim Pract 16:669-685

Berger L, Speare R, Daszak P, Green DE and others (1998) Chytridiomycosis causes amphibian mortality associated with population declines in the rain forests of Australia and Central America. Proc Natl Acad Sci USA 95: 9031-9036

Boyle DG, Boyle DB, Olsen V, Morgan JAT, Hyatt AD (2004) Rapid quantitative detection of chytridiomycosis (Batrachochytrium dendrobatidis) in amphibian samples using real-time Taqman PCR assay. Dis Aquat Org 60:141-148

Carey C, Cohen N, Rollins-Smith L (1999) Amphibian declines: an immunological perspective. Dev Comp Immunol 23:459-472

Churgin SM, Raphael BL, Pramuk JB, Trupkiewicz JG, West G (2013) Batrachochytrium dendrobatidis in aquatic caecilians (Typhlonectes natans): a series of cases from two institutions. J Zoo Wildl Med 44:1002-1009

Daszak P, Berger L, Cunningham AA, Hyatt AD, Green DE, 
Speare R (1999) Emerging infectious diseases and amphibian population declines. Emerg Infect Dis 5:735-748

Groff JM, Mughannam A, McDowell TS, Wong A, Dykstra MJ, Frye FL, Hedrick RP (1991) An epizootic of cutaneous zygomycosis in cultured dwarf African clawed frogs (Hymenochirus curtipes) due to Basidiobolus ranarum. J Med Vet Mycol 29:215-223

Hey D (1986) Water and wildlife. Timmins Publishers, Cape Town

> Johnson ML, Berger L, Philips L, Speare R (2003) Fungicidal effects of chemical disinfectants, UV light, desiccation and heat on the amphibian chytrid Batrachochytrium dendrobatidis. Dis Aquat Org 57:255-260

Karling JS (1977) Chytridiomycetarum iconographia: an illustrated and brief descriptive guide to the chytridiomycetous genera with a supplement of the Hyphochytriomycetes. Lubrecht \& Cramer, Monticello, NY

Marcum RD, St-Hilaire S, Murphy PJ, Rodnick KJ (2010) Effects of Batrachochytrium dendrobatidis infection on ion concentrations in the boreal toad Anaxyrus (Bufo) boreas boreas. Dis Aquat Org 91:17-21

Mazzoni R (2003) Emerging pathogen of wild amphibians in frogs (Rana catesbeiana) farmed for international trade. Emerg Infect Dis 9:995-998

Mutschmann F, Berger L, Zwart P, Gaedicke C (2000) Chytridiomycosis in amphibians - first report in Europe. Berl Münch Tierärztl Wochenschr 113:380-383 (in German with English abstract)

Editorial responsibility: Louise Rollins-Smith, Nashville, Tennessee, USA
Parker JM, Mikaelian I, Hahn N, Diggs HE (2002) Clinical diagnosis and treatment of epidermal chytridiomycosis in African clawed frogs (Xenopus tropicalis). Comp Med 52:265-268

Pessier AP, Nichols DK, Longcore JE, Fuller MS (1999) Cutaneous chytridiomycosis in poison dart frogs (Dendrobates spp.) and White's tree frogs (Litoria caerulea). J Vet Diagn Invest 11:194-199

> Rachowicz LJ, Vredenburg VT (2004) Transmission of Batrachochytrium dendrobatidis within and between amphibian life stages. Dis Aquat Org 61:75-83

$>$ Raverty S, Reynolds T (2001) Cutaneous chytridiomycosis in dwarf aquatic frogs (Hymenochirus boettgeri) originating from southeast Asia and in a western toad (Bufo boreas) from northeastern British Columbia. Can Vet J 42:385-386

$>$ Reed KD, Ruth GR, Meyer JA, Shukla SK (2000) Chlamydia pneumoniae infection in a breeding colony of African clawed frogs (Xenopus tropicalis). Emerg Infect Dis 6: 196-199

Sparrow FK (1960) Aquatic phycomycetes. University of Michigan Press, Ann Arbor, MI

> Voyles J, Young S, Berger L, Campbell C and others (2009) Pathogenesis of chytridiomycosis, a cause of catastrophic amphibian declines. Science 326:582-585

Weldon C, du Preez LH, Hyatt AD, Muller R, Spears R (2004) Origin of the amphibian chytrid fungus. Emerg Infect Dis 10:2100-2105

Submitted: August 7, 2014; Accepted: January 21, 2015 Proofs received from author(s): March 24, 2015 